\title{
Analisis Kegiatan Customer Relationship Management Melalui Membership Card Untuk Meningkatkan Loyalitas Konsumen: Studi Kasus Pada Sogo Premier Card
}

\author{
Wibowo Soedjono, Frendy Limantoro \\ London School of Public Relations Jakarta \\ E-mail: wibowosoedjono@gmail.com
}

\begin{abstract}
Abstrak. Persaingan yang terjadi di berbagai industri di Indonesia semakin ketat. Berbagai perusahaan berlomba-lomba untuk menjadi yang terdepan di benak konsumen. Strategi demi strategi diterapkan salah satunya strategi Customer Relationship Management (CRM) yang dilakukan oleh PT. Panen Lestari Internusa dengan meluncurkan Sogo Premier Card sebagai bentuk kartu keanggotaan bagi konsumennya. Penelitian ini merupakan penelitian dengan pendekatan kualitatif yang menganalisa bagaimana strategi CRM diimplementasikan oleh PT. Panen Lestari Internusa. Teknik wawancara yang digunakan adalah wawancara semi terstruktur dengan dua narasumber internal yang berasal dari pihak PT. Panen Lestari Internusa serta empat narasumber eksternal selaku pengguna SPC dan dua narasumber ahli. Teknik analisis data pada penelitian ini menggunakan teknik coding dengan teknik pemeriksaan keterpercayaan menggunakan triangulasi sumber. Hasil penelitian menunjukkan bahwa penggunaan Sogo Premier Card sebagai bentuk dari CRM dinilai membantu meningkatkan loyalitas konsumen Sogo Department Store dengan tiga komponen elemen penting yakni reward based bonds, selection dan interaction.
\end{abstract}

Kata Kunci: customer relation management, loyalitas konsumen, membership card

\begin{abstract}
Competition in various industries in Indonesia is getting tighter. Various companies are competing to be at the forefront of the minds of consumers. Strategy for strategy is implemented, one of them is Customer Relationship Management (CRM) strategy conducted by PT. Panen Lestari Internusa by launching Sogo Premier Card as a form of membership card for its customers. This research is a research with a qualitative approach that analyzes how CRM strategies are implemented by PT. Panen Lestari Internusa. The interview technique used was a semi-structured interview with two internal speakers from PT. Panen Lestari Internusa and four external informant whom are SPC members and two marketing communication expertise. Data analysis techniques in this study used coding techniques with reliability checking techniques using source triangulation. The results showed that the use of Sogo Premier Card as a form of CRM was considered to help increase the loyalty of Sogo Department Store consumers with three important elements such as reward based bonds, selection and interaction.
\end{abstract}

Keywords: customer relation management, consumer loyalty, membership card

\section{Pendahuluan}

Persaingan yang semakin ketat menuntut setiap perusahaan dari berbagai jenis industry di Indonesia seperti industri perbankan, pangan, tekstil, pariwisata, pertambangan, hingga minyak dan bahan bakar untuk terus berinovasi dan berkreasi untuk tetap bertahan dalam berkompetisi dengan kompetitor-kompetitor yang bergelut di industri serupa. Indonesia sebagai negara yang sedang berkembang menjadi salah satu pasar yang diperhatikan oleh para pebisnis dunia dari berbagai 
sektor. Perkembangan persaingan di industri ritel fashion juga tentunya sangatlah ketat. Indonesia, meski dikenal dengan jumlah penduduknya yang berada pada posisi keempat terbesar di dunia, tentunya bagi para pemain industri ritel fashion untuk dapat terus bersaing perlu memberlakukan strategi-strategi yang tepat guna mempertahankan eksistensi di pasar Indonesia yang begitu besar.

Perkembangan industri fashion di Indonesia semakin menunjukkan geliat yang positif. Hal ini didukung juga oleh data survei Badan Ekonomi Kreatif (Bekraf) dan Badan Pusat Statistik (BPS) yang mengumumkan bahwa sektor ekonomi kreatif menyumbang 7,83 persen terhadap total perekonomian nasional tahun 2016 dan sektor fashion memberikan kontribusi sebesar 18,15 persen atau peringkat dua setelah industri kuliner. (Margaretta, 2017).

Kerasnya persaingan membuat PT. Matahari Department Store Tbk pada akhir tahun 2017 juga secara resmi menutup beberapa gerainya di Ibukota. PT. Matahari Departement Store Tbk menutup empat gerainya yang berada di Pasaraya Blok M dan Manggarai pada bulan September 2017, Lombok City pada November 2017 dan Mal Taman Anggrek pada awal Desember 2017 yang lalu. (Kertiyasa, 2018).

Kejadian yang hampir serupa juga dialami oleh salah satu ritel ternama di Indonesia. PT. Mitra Adi Perkasa juga menutup gerai ritel fashion Lotus Department Store dan Debenhams dikarenakan tidak memberikan untung yang sesuai. Namun penutupan gerai-gerai tersebut disebutkan oleh CEO Sogo Department Store, Handoko Santosa sebagai salah satu langkah bisnis dan salah satu gerai yang ditutup pun langsung digantikan dengan pembukaan toko Sogo di lokasi yang ditutup sebelumnya di Karawaci, Tangerang. (Akbarayansyah, 2017).

Berbagai upaya dan inovasi terus dilakukan oleh perusahaan-perusahaan besar yang bergerak di bidang fashion salah satunya dengan mulai memasuki ranah $e$ commerce dan pemberlakuan program kartu keanggotaan bagi setiap konsumen yang berbelanja di toko secara langsung. PT. Panen Lestari Internusa dibawah naungan PT. Mitra Adi Perkasa Tbk yang menaungi tiga perusahaan besar department store yakni Sogo, Seibu dan Galeries Lafayette juga memberlakukan sistem Customer Relationship Management atau CRM bagi para konsumennya.

Pada mulanya Sogo Premier Card (SPC) diluncurkan pada bulan Juni 2012. Sejak diluncurkan hingga Agustus 2016, keempat kartu dibawah naungan PT. Mitra Adi Perkasa (termasuk juga dengan Sogo Premier Card) bergerak dengan sistem dan fungsi masing-masing sesuai dengan segmentasi pasar setiap brand. Namun pada Agustus 2016, keempat kartu tersebut (Fidelite, Seibu Aicard, Sogo Premiere Card dan MAP CLUB) digabungkan fungsi dan fitur-fiturnya.

Berdasarkan data yang diperoleh dari tim Customer Relationship Management PT. Panen Lestari Internusa, total pengguna atau anggota dari MAP CLUB secara keseluruhan mencapai 2 juta anggota. Lebih lanjut, sebanyak 1 juta pengguna/anggota atau setengah dari total keseluruhan merupakan orang yang berbelanja di Sogo Department Store. Hal inilah yang membuat peneliti tertarik untuk meneliti lebih lanjut soal aplikasi SPC.

SOGO Premier Card sebagai wujud membership card dalam aplikasinya telah bekerjasama dengan lebih dari 30 brand ternama. Penggunaan kartu keanggotaan ini memberikan kebebasan bagi konsumen pada saat bertransaksi untuk dapat mengumpulkan poin dan menggunakan poin yang sudah diterima sebelumnya. 
Partnership yang dilakukan oleh pihak Sogo Premier Card mengungguli partnership ketiga kartu membership lainnya yakni MAP CLUB, Seibu Aicard dan Fidelite.

Program membership card berupa Sogo Premiere Card dalam penelitian ini tidak hanya sebagai salah satu bentuk dari Customer Relationship Management, namun juga berfungsi sebagai alat untuk berkomunikasi kepada pelanggan mengenai programprogram baru yang diluncurkan oleh Sogo Department Store serta keuntungankeuntungan yang bisa diperoleh pemegang membership card. Penelitian ini meneliti kegiatan Customer Relationship Management yang dilakukan oleh Sogo Department Store melalui membership card Sogo Premier Card bagi para konsumennya.

Untuk mengetahui bagaimana penerapan kegiatan Customer Relationship Management pada Sogo Premier Card, berikut akan diuraikan tinjauan mengenai Customer Relationship Management, elemen-elemen membership card dan loyalitas konsumen.

Customer Relationship Management (CRM) adalah sebuah proses untuk membangun dan mempertahankan hubungan dengan konsumen yang menguntungkan dengan memberikan nilai lebih serta tingkat kepuasan yang tinggi bagi konsumen (Kotler \& Armstrong, 2011, p.12).

Sedangkan Kumar (2012, p.5) menyatakan bahwa Customer Relationship Management merupakan sebuah proses strategi untuk menyeleksi konsumen yang dilakukan oleh sebuah perusahaan guna memberikan servis terbaik serta membentuk interaksi antar perusahaan dengan konsumen dengan tujuan pencapaian utama untuk memaksimalkan nilai dari konsumen yang sudah ada maupun konsumen yang memiliki potensial untuk menggunakan produk atau jasa dari perusahaan.

Beberapa komponen utama yang dalam Customer Relationship Management (CRM) terdiri dari:

1. Strategic Process, yakni proses CRM diinisiasi dan dilaksanakan dari bagian tertinggi sebuah organisasi. Proses ini sendiri menuntut keseluruhan fungsi dan kontribusi perusahaan dalam skala luas. Selain itu, proses CRM harus dilakukan secara berkelanjutan dan berkesinambungan untuk menghasilkan sebuah perusahaan yang berorientasi pada konsumen.

2. Selection, yakni setelah merumuskan strategi yang akan digunakan oleh perusahaan dalam menjalankan CRM, maka perusahaan melakukan seleksi dan memfokuskan alokasi pada konsumen yang dianggap mampu memberikan profit atau keuntungan lebih besar dan banyak bagi perusahaan. Hal ini tentunya tidak mengabaikan servis pada konsumen lainnya.

3. Interactions, sebuah perusahaan dalam interaksinya dengan konsumen pada umumnya terjadi hanya dalam koridor penjualan barang atau jasa pada konsumennya. Namun dalam CRM, interaksi tersebut kemudian berkembang menjadi sebuah interaksi dua arah dimana konsumen dan perusahaan saling bertukar informasi.

4. Customers, konsumen menjadi sebuah elemen yang sangat penting bagi sebuah proses CRM. Dalam proses CRM, konsumen tidak hanya terbatas pada pengguna akhir saja, namun juga mencakup berbagai distributor, 
pengecer/retailer dan berbagai penengah lainnya yang saling berhubungan satu dengan lainnya dengan perusahaan.

5. Current and the future value of the customer, mengoptimalisasikan nilai kepuasan bagi konsumen yang sudah ada saat ini maupun bagi para calon konsumen bagi sebuah perusahaan berarti akan membuat perusahaan tersebut bergerak dari transaksi yang bersifat tunggal beralih kepada untuk memaksimalkan keuntungan maupun profit dari berbagai transaksi yang sifatnya luas. Sebuah perusahaan tentunya ingin meningkatkan ekuitas dari konsumennya yang dimaksudkan kedalam hubungan dengan konsumen (Kumar, 2012, p.5).

Sebuah perusahaan produk maupun jasa tentunya ingin meningkatkan kepuasan konsumen akan produk dan jasa yang ditawarkan dari perusahaan tersebut. Sederhananya, kepuasan konsumen dianggap akan membangun loyalitas dan daya ingat konsumen akan produk ataupun jasa. Dari sudut pandang strategi pemasaran, tentunya proses identifikasi dan pemeliharaan hubungan dengan konsumen menjadi suatu hal penting yang harus diperhatikan oleh perusahaan. Oleh karena itu, pada taraf ini dikenal sebuah istilah yakni program loyalitas.

Program loyalitas merupakan suatu bentuk dari Customer Relationship Management (CRM) yang digunakan sebagai alat yang dapat mengidentifikasi, menghargai, dan berhasil mempertahankan konsumen yang dianggap menguntungkan bagi perusahaan.

Program loyalitas mencakup beberapa jenis diantaranya frequency reward programs, customer club, customer card serta membership card. Program loyalitas konsumen yang dikemas dalam bentuk kartu keanggotaan (membership card) merupakan salah satu cara yang dapat digunakan untuk mempertahankan konsumen (Kotler \& Keller, 2012, p. 142).

Beberapa manfaat dari program membership card ini, diantaranya:

\section{Reward-Based Bonds}

Dalam kajian ini, hadiah yang ditawarkan kepada konsumen berbentuk baik finansial maupun non finansial. Penawaran bentuk finansial yang ditawarkan oleh perusahaan dapat berupa diskon atau potongan harga ketika melakukan transaksi dengan menggunakan kartu keanggotaan. Selain itu, terdapat pula beberapa perusahaan yang membuat program pengumpulan poin setiap melakukan transaksi. Poin-poin tersebut bila sudah terakumulasi nantinya dapat ditukarkan dengan berbagai hadiah atau merchandise yang unik ataupun fasilitas tertentu yang ditawarkan oleh perusahaan tersebut.

\section{Social Bonds}

Manfaat yang ditawarkan dalam social bonds adalah ikatan hubungan sosial dengan konsumennya. Ikatan sosial yang terjalin dengan konsumen akan mempertahankan hubungan antar perusahaan dengan konsumen dalam jangka waktu yang panjang.

\section{Customization Bonds}

Customization Bonds merupakan suatu hubungan yang lebih individu antara perusahaan dengan konsumen. Perusahaan dalam hal ini memegang database 
dari konsumen sekaligus memberi akses bagi pihak perusahaan untuk mengetahui dan mengikuti rekam jejak pembelian maupun transaksi konsumen.

\section{Structural Bonds}

Ikatan struktural ini memberikan akses bagi perusahaan untuk membangun hubungan jangka panjang dengan konsumen. Hal ini memudahkan konsumen untuk melakukan transaksi, contohnya dengan penyediaan situs resmi yang bisa diakses oleh konsumen dengan informasi-informasi seputar perusahaan, visi misi, kinerja, hingga produk-produk yang dimiliki oleh perusahaan tersebut. (Lovelock \& Wirtz, 2010, p. 334-336).

Loyalitas berasal dari pemenuhan harapan atau harapan konsumen, sedangkan ekspektasi sendiri berasal dari pengalaman pembelian terdahulu oleh konsumen, opini dari teman dan kerabat, dan janji atau informasi dari pemasar atau pesaing (Japarianto, 2010, p. 16).

Loyalitas konsumen lebih lanjut merupakan sebuah komitmen untuk membeli kembali atau menjadi pelanggan dari sebuah produk ataupun jasa yang dipilih. Perilaku pembelian ulang ini dikarenakan beberapa faktor yang mempengaruhi seorang konsumen untuk loyal pada merek tersebut. Hal ini mencakup faktor harga yang mendasar serta juga faktor kebiasaan seseorang yang telah terbiasa untuk menggunakan produk atau jasa tersebut (Kotler \& Keller, 2012, p.165).

Lima indikator dari loyalitas konsumen, yakni:

1. Repeat purchase, hal ini merupakan kecenderungan konsumen untuk melakukan pembelian kembali dalam skala yang lebih banyak dan jangka waktu yang berulang dan intensif.

2. Cross or Add-on Selling, dalam hal ini yang dimaksudkan adalah ketika konsumen melakukan cross selling yang berarti adanya pembelian lebih dari satu produk yang ditawarkan.

3. Willingness to pay a price premium (not price sensitive), adalah ketika seorang konsumen yang loyal dengan tidak pikir panjang akan bersedia membeli produk yang memiliki harga premium sekalipun. Konsumen tidak sensitif terhadap perubahan harga yang timbul.

4. Positive word-of-mouth, bila seorang konsumen loyal maka akan timbul word of mouth yang positif dari seorang konsumen yang ditandai dengan diberitakannya hal-hal positif kepada orang-orang lain disekitarnya.

5. Product Recomendation, adalah terjadinya rekomendasi produk barang maupun jasa dari sebuah perusahaan yang dilakukan konsumen kepada orang orang-orang disekitarnya. (Dewi, et al, 2012, p.19).

Berdasarkan latar belakang diatas, maka peneliti tertarik untuk melihat bagaimana kegiatan Customer Relationship Management yang dilakukan oleh Sogo Department Store melalui program Membership Card kepada konsumennya dapat meningkatkan loyalitas konsumen serta melihat faktor apa yang menjadi hambatan dalam pelaksanaannya serta aplikasi solusi dalam mengatasi hambatan yang timbul. 


\section{Metode Penelitian}

Penelitian ini menggunakan pendekatan kualitatif deksriptif dengan analisis terhadap strategi Customer Relationship Management melalui elemen-elemen yang terdapat dalam membership card yang diimplementasikan oleh PT. Panen Lestari Internusa.

Data kualitatif melibatkan dokumentasi kejadian-kejadian nyata, peliputan apa yang dibicarakan oleh seorang individu (dengan kata-kata, gerak tubuh, dan nada), melakukan observasi pada sebuah perilaku spesifik, mempelajari dokumen tertulis dan pemeriksaan gambar visual (Neumann, 2006, p. 157).

Oleh karena itu, sumber data yang akan dimanfaatkan dalam penelitian ini diperoleh dari berbagai sumber, antara lain:

\section{Data Primer}

Teknik pengumpulan data primer yang digunakan dalam penelitian ini adalah dengan wawancara. Wawancara merupakan pertemuan dua orang untuk bertukar informasi dan ide melalui tanya jawab, sehingga dapat dikonstruksikan makna dalam topik tersebut. Beberapa jenis wawancara, salah satunya yang digunakan dalam penelitian ini adalah wawancara semiterstruktur (Semistructure Interview).

Wawancara ini sudah termasuk ke dalam kategori in-depth interview, dimana dalam pelaksanaannya lebih bebas bila dibandingkan dengan wawancara terstruktur. Tujuan dari wawancara ini adalah untuk menemukan permasalahan secara lebih terbuka, dimana pihak yang diajak wawancara diminta pendapat serta ide-idenya (Sugiyono, 2009, p.231).

\section{Data Sekunder}

Data sekunder dalam penelitian ini diperoleh melalui penelurusan peneliti melalui situs-situs resmi milik Sogo maupun PT. Panen Lestari Internusa, berbagai portal berita yang menyajikan fakta-fakta seputar Sogo serta profil perusahaan maupun data internal perusahaan seputar Sogo Departement Store.

Teknik analisis data yang digunakan dalam penelitian ini mengacu pada teknik analisis data yang diperkenalkan oleh Neuman (2006) mengutip dari Strauss (1987) yang mendefinisikan terdapat tiga macam proses pengkodean data di dalam penelitian kualitatif. Ketiga proses tersebut mencakup open coding, axial coding, dan selective coding (Neumann, 2006, p.158).

Dalam sebuah penelitian, menjadi sebuah hal yang sangat penting untuk melakukan pemeriksaan tingkat akurasi dari temuan dan interpretasi data yang sudah didapat. Peneliti perlu memastikan akurasi dan kredibilitas data yang didapat dengan memvalidasi temuan yang ada dalam bentuk triangulasi atau member checking (Creswell, 2012, p.259).

Penelitian ini menggunakan teknik triangulasi untuk pengujian kredibilitas data yang diperoleh. Teknik triangulasi yang digunakan merupakan triangulasi sumber. Menurut Patton (dalam Moleong, 2010, p.330) teknik ini merupakan teknik yang membandingkan dan mengecek balik derajat kepercayaan suatu informasi yang diperoleh melalui waktu dan alat yang berbeda dalam penelitian kualitatif. 
Informan internal dalam penelitian ini mencakup para petinggi PT. Panen Lestari Internusa yang diwawancarai oleh peneliti untuk mendapatkan data-data yang relevan dan berguna dalam penelitian diantaranya Abraham Chandra dan Nianti Samsi.

Selain itu, dalam tahapan triangulasi sumber, peneliti mewawancarai dua narasumber ahli di bidang Marketing Communication yakni Dra. Gracia Rachmi Adiarsi, M.M dan Robby Susatyo. Peneliti juga mewawancarai informan eksternal perusahaan yakni para pemegang kartu SPC diantaranya, Gracellya, Meliana Kurniawan, Harry Yusuf dan Christian Hartono. Keempat konsumen pemegang kartu SPC memiliki karakteristik yang berbeda-beda dari segi intensitas berbelanja, tingkat spending pada saat melakukan transaksi serta lama menjadi anggota dari SPC.

Ibu Gracellya merupakan seorang ibu rumah tangga berusia 40 tahun yang memiliki intensitas kunjungan ke Sogo Department Store sebanyak kurang lebih 10 kali per tahunnya. Sedangkan Ibu Meliana juga merupakan ibu rumah tangga berusia 40 tahun, namun intensitas kunjungan ke Sogo Department Store hanya berkisar antara 3 hingga 5 kali pertahunnya. Informan berikutnya yakni Harry Yusuf merupakan seorang kepala rumah tangga yang intensitas kunjungannya berkisar antara 6 kali pertahunnya. Disamping itu, Christian Hartono merupakan seorang karyawan swasta berstatus lajang yang intensitas kunjungan ke Sogo Department Store hanya 1 hingga 2 kali pertahunnya.

\section{Hasil dan Pembahasan}

Program membership card Sogo Premier Card yang diluncurkan pada Juni 2012 yang lalu merupakan proyek pertama yang dilakukan perusahaan ini sebelum nantinya bergabung dengan kartu-kartu keanggotaan lainnya seperti MAP CLUB dan sebagainya.

Proses implementasi kartu Sogo Premier Card ini pada mulanya juga dinilai sangat lambat pergerakannya, hal ini didapat dari data yang menunjukkan bahwa hanya sekitar 20 hingga 30 persen dari penjualan/sales yang terjadi dilakukan oleh pengguna kartu SPC.

Sejak awal diluncurkan terdapat syarat bagi konsumen yang ingin mendaftarkan dirinya sebagai anggota dari SPC. Untuk bergabung, seorang konsumen harus berbelanja minimal sebesar $\mathrm{Rp} 500.000,00$ dan melakukan pengisian form keanggotaan di lokasi berbelanja. Namun, seiring berjalannya waktu, barrier tersebut pun dihilangkan dengan tujuan agar akuisisi konsumen yang mendaftarkan dirinya sebagai anggota SPC meningkat.

"Dulu sebelum join di sogo itu harus belanja minimal 500.000 baru bisa membuat SPC sekarang siapa saja buat dan itu per gabung siapa saja bisa, karena dulu itu mau bikin SPC eksklusif banget karena kita tuh udah susah-susah cari partnership ada 30, mau ke hotel apa diskon 10 persen, kadang-kadang ga banyak customer notice itu." (C. Abraham, wawancara, 20 Agustus 2018).

Hal ini sebanding dengan pernyataan Kumar (2012, p.5) yang mengatakan bahwa dalam proses CRM setelah merumuskan strategi yang akan dijalankan oleh perusahaan, langkah berikutnya adalah dilakukannya penyeleksian konsumen yang dianggap mampu memberikan profit atau keuntungan lebih besar bagi perusahaan. 
Bentuk interaksi yang dibangun dari PT. Panen Lestari Internusa dalam hal ini Sogo Department Store kepada konsumennya adalah dengan melalui e-mail yang dikirimkan kepada para konsumennya yang sudah bergabung ke dalam Sogo Premier Card. E-mail tersebut berisikan promo-promo hingga kegiatan yang sedang ataupun akan dilakukan di waktu yang akan datang. Namun dari hasil temuan dengan ditemukan oleh peneliti pada konsumen, sebagian besar konsumen mengaku bahwa mereka jarang mengecek e-mail pribadi mereka.

"Hmm, pasti mereka catet semua data-data aku, kalau aku sih biasa mereka pakai SMS ya, kadang-kadang pakai email juga, mungkin juga karna akunya yang suka ga buka email, karna lupa." (Gracellya, wawancara, 11 September 2018).

Oleh sebab itu, komunikasi yang dilakukan oleh Sogo Department Store akan lebih efektif menjalin hubungan dua arah dengan konsumennya pada media yang mempertemukan kedua belah pihak secara langsung atau ada interaksi dua arah (lewat telepon) dan tidak hanya sebatas lewat email ataupun sms saja.

Hal ini tentunya sesuai dengan pernyataan Kumar (2012, p.5) yang menyampaikan bahwa dalam proses interaksi dalam CRM, interaksi yang terjalin akan berkembang tidak hanya sebatas interaksi satu arah (dari perusahaan kepada konsumen saja), namun akan ada komunikasi dua arah yang terbangun serta adanya feedback dimana perusahaan dan konsumen dapat saling bertukar informasi.

Sosialisasi kartu Sogo Premier Card yang dilakukan oleh Sogo Department Store tidak hanya dilakukan lewat penawaran di toko saja, namun juga dilakukan lewat media konvensional seperti radio, majalah, televisi dan media koran.

Berbagai cara akuisisi dilakukan salah satunya melalui penawaran yang dilakukan setiap kali oleh pihak SPG di toko. Ketika seorang konsumen melakukan transaksi, kasir/SPG yang sedang bertugas akan menanyakan perihal keanggotaan Sogo Premier Card, apabila konsumen tersebut belum mempunyainya, maka akan ditawarkan untuk pendaftaran keanggotaan.

Data-data konsumen yang baru ini tidak hanya dibiarkan begitu saja oleh pihak Sogo Department Store. Namun ada penawaran-penawaran khusus yang diberikan oleh Sogo kepada konsumennya. Penawaran khusus tersebut berbeda dari seorang konsumen kepada konsumen lainnya sesuai dengan segmentasi yang sudah dikerucutkan melalui data konsumen yang terekam.

Hal ini sebanding dengan pernyataan Kumar (2012, p.5) yang menyatakan bahwa tujuan utama dari proses CRM adalah untuk memaksimalkan data konsumen yang sudah didapatkan oleh perusahaan dan dilakukan sejalan dengan proses akuisisi konsumen-konsumen baru lainnya.

Dalam keempat elemen membership card, yakni reward-based bonds, social bonds, customization bond, dan structural bonds, elemen yang paling menonjol adalah elemen reward-based bonds. Hal ini ditandai dengan konsumen yang selalu menggunakan kartu SPC ketika mereka berbelanja, baik secara langsung mengumpulkan poin ataupun tidak. Konsumen pengguna SPC menyatakan benefit yang mereka rasakan tidak hanya terbatas pada poin saja, namun juga mencakup promosi demi promosi yang mereka terima ketika menjadi anggota dari SPC. 
"Karna dia punya promo-promonya bagus yah, kalau kita belanja dengan 1-2 juta misalkan, dia ada pemotongan, pemotongan berapa gitu, dan itu memicu kita untuk belanja-belanja lagi." (Gracellya, wawancara, 11 September 2018).

Indikator pertama dari loyalitas konsumen adalah adanya repeat purchase yakni kecenderungan konsumen untuk melakukan pembelian kembali terhadap suatu produk ataupun jasa yang sudah pernah dibeli sebelumnya. (Dewi, et al, 2012, p.19)

Konsumen Sogo Department Store yang menjadi informan dalam penelitian ini mengaku bahwa mereka cenderung melakukan repeat purchase di store Sogo. Di samping itu, bagi mereka yang sudah melewati tahap merasakan benefit dari penggunaan kartu SPC ini, mereka akan cenderung lebih tertarik terhadap cross or add on selling yang ditawarkan oleh pihak Sogo Department Store sebagai bentuk promosi kepada para pengguna kartu SPC.

"Setelah belanja biasa mereka memberikan diskon, dan biasa kita langsung pakai juga sih hari itu juga." (K. Meliana, wawancara, 11 September 2018).

Poin berikutnya dalam elemen loyalitas konsumen yang menjadi tolak ukur bahwa seorang konsumen sudah loyal adalah terciptanya word of mouth yang positif serta ditandai dengan adanya rekomendasi produk atau jasa kepada rekan, kolega, maupun orang di sekitar mereka.

Hasil wawancara dengan konsumen yang menggunakan SPC didapati bahwa sebagian besar konsumen merekomendasikan kartu tersebut kepada orang-orang disekitar mereka, baik rekan, kerabat maupun teman.

"Oh iya, banyak, kayak aku kasih tau ke sodara-sodara, kayak cici, kayak temen-temen, eh lu mendingan pakai ini, lu ada membernya gak? kalau ga ada membernya eh lu bikin lah, kalau engga pakai punya gua lah, poinnya masukkin ke gua ntar dapat voucher." (Gracellya, wawancara, 11 September 2018)

Peneliti menemukan bahwa dalam proses CRM ini ada beberapa elemen yang menjadi elemen terpenting, diantaranya:

1. Reward Based Bonds, hal ini terlihat di kalangan konsumen bahwa sebagian dari mereka merasa terbantu dengan adanya sistem poin reward yang diberikan oleh pihak perusahaan sebagai benefit yang mereka dapatkan. Selain dalam bentuk poin, konsumen juga mendapatkan reward dalam bentuk voucher maupun potongan-potongan diskon pada saat berbelanja menggunakan SPC di Sogo Department Store.

2. Interaction, yakni kemampuan mengkomunikasikan berbagai pesan yang ingin disampaikan dari pihak SOGO berupa promo, event, ataupun informasi-informasi kepada konsumen pemegang kartu keanggotaan menjadi penting. Hal ini dikarenakan dengan terus adanya inisiatif menjalin hubungan dari pihak perusahaan kepada konsumen, maka konsumen tersebut akan merasa dihargai dan dipedulikan dan mereka akan memiliki kemungkinan untuk aware terhadap informasi dari SOGO.

3. Selection, merupakan salah satu elemen yang juga penting seperti pernyataan dari salah satu informan ahli bahwa jarang sekali ada perusahaan yang melaksanakan kegiatan CRM berupa membership card di Indonesia mengelola dan mempelajari secara mendetil data profil konsumennya dan melakukan segmentasi mendalam dengan membagi konsumen sesuai 
dengan karakteristik dan keunikan perilakunya masing-masing. Hal ini menjadi penting karna dapat membantu kedua poin yang sudah disebutkan peneliti sebelumnya, baik ketika sebuah perusahaan ingin memberikan Reward Based Bonds serta berinteraksi dengan konsumennya, metode atau cara penyampaian dari perusahaan akan menjadi jelas dan terintegrasi dengan tepat sesuai dengan karakteristik konsumen yang sudah dikelompokkan sebelumnya. Pada SOGO Department Store, disebutkan bahwa SOGO membagi anggota SPCnya ke dalam berbagai kotak karakteristik diantaranya dari intesitas kunjungan serta jumlah uang yang dikeluarkan dalam sebuah transaksi hingga kemudian nantinya akan diberikan perlakuan dan promosi-promosi berbeda sesuai dengan karakteristik tersebut.

\section{Kesimpulan}

Proses Customer Relationship Management yang terjalin sangatlah baik antar konsumen dan perusahaan. Hal ini terbukti dari adanya repeat purchase dan product recommendation oleh konsumen. Dalam proses CRM ini elemen yang terpenting dan saling berkaitan satu dengan yang lainnya diantaranya reward based bonds berupa promo-promo, diskon atau potongan, interaction yang dibangun oleh perusahaan dan dipelihara secara terus-menerus, serta selection yakni pengelompokkan konsumen sesuai dengan karakteristik masing-masing.

Namun dalam pelaksanaannya terdapat beberapa hambatan-hambatan yang timbul baik dari segi konsumen maupun pihak Sogo Department Store.

Hambatan yang muncul dari segi konsumen adalah kurangnya tingkat konsumen membaca info yang disampaikan oleh pihak Sogo melalui email, hal ini terlihat dari data yang dimiliki oleh Sogo bahwa hanya sebesar 20 persen saja konsumen yang membaca email yang dikirimkan. Data tersebut didukung oleh pernyataan beberapa konsumen yang mengakui bahwa mereka jarang membuka email pribadi mereka. Masalah ini dicoba diatasi oleh pihak Sogo Department Store dengan para SPG yang mengingatkan promo yang sedang berjalan pada saat konsumen berbelanja ataupun dengan telepon secara langsung kepada konsumen yang dinilai cukup memberikan kontribusi besar bagi perusahaan dalam transaksinya. Namun, solusi ini belum dapat dilakukan secara menyeluruh dikarenakan besarnya biaya yang akan dikeluarkan untuk menghubungi para konsumen dengan telepon.

Sedangkan hambatan yang muncul dari pihak Sogo Department Store dalam pengaplikasian kartu SPC adalah masalah system yang seringkali offline ketika konsumen ingin menggunakan kartu. Sistem yang terkadang offline membuat konsumen yang ingin menggunakan poin atau mengumpulkan poin pada saat transaksi terganggu dan harus memasukkan poin secara manual. Solusi yang dilakukan oleh pihak Sogo untuk mengatasi masalah ini adalah dengan meningkatkan kinerja dari bagian IT perusahaan serta mengembangkan sistem membership online lewat aplikasi dari gadget konsumen.

Lebih lanjut, pihak Sogo Department Store perlu meningkatkan pemantauan secara lebih berkala untuk setiap SPG yang bertugas dan memotivasi para SPG yang merupakan garis terdepan dalam interaksi dengan konsumen. Hal ini dikarenakan interaksi menjadi penting dalam proses CRM, sehingga SPG sebagai garda terdepan 
dari perusahaan yang bertemu langsung dengan konsumen perlu diedukasi dan dipantau dengan baik.

Selain itu, perlu adanya perbaikan perlu adanya perbaikan sistem penggunaan kartu keanggotaan yang terkadang offline ketika konsumen ingin melakukan transaksi. Hal ini mengingat konsumen yang menjadi rata-rata usia berada pada usia 40 tahun (usia yang tidak begitu terbiasa dengan teknologi) sehingga akan sangat menyulitkan mereka apabila mereka harus melakukan pendaftaran poin secara manual.

\section{Daftar Pustaka}

Akbarayansyah, A. (2017, November 1). Bos Sogo Buka-bukaan Soal Tutupnya Lotus dan Debenhams. Diakses dari https:/ / finance.detik.com/berita-ekonomibisnis/d-3709732/bos-sogo-buka-bukaan-soal-tutupnya-lotus-dan-debenhams

Dewi, N. K., et al. (2012). Pengaruh Iklan, Citra Merek, dan Kepuasan Konsumen terhadap Loyalitas Konsumen Dalam Menggunakan Vaseline Hand and Body Lotion di Kota Padang (Studi Kasus di PT. Unilever Cabang Padang), Jurnal Manajemen dan Kewirausahaan, Vol.3(2), 11-29

Japarianto, E. (2010). Sikap Relatif dan Komitmen Jangka Panjang Konsumen dalam Model Loyalitas. Jurnal Manajemen Pemasaran, 5(1), 14-21

Kertiyasa, M. B. (2018, April 3). Tutup 4 Gerai Tahun Lalu, Matahari Berencana Buka 6 Gerai Sebelum Lebaran. Diakses dari https://economy.okezone.com/read/2018/04/03/320/1881539/tutup-4-geraitahun-lalu-matahari-berencana-buka-6-gerai-sebelum-lebaran

Kotler, P. \& Armstrong, G. (2011). Principles of Marketing 12th Edition. New Jersey: Pearson Education Limited

Kumar, V. (2012). Customer Relationship Management: Concept, Strategy, and Tools. London: Springer

Lovelock, C. \& Wirtz, J. (2010). Service Marketing People Technology, Strategy 7th Edition. British: Pearson Practice Hall.

Margaretta, Y. (2017, November 13). Masyarakat Indonesia Semakin Sadar Mode dan Siap Terjun ke Industri Fashion. Diakses dari http://wartakota.tribunnews.com/2017/11/13/masyarakat-indonesiasemakin-sadar-mode-dan-siap-terjun-ke-industri-fashion

Moleong, L. J. (2010). Metode Penelitian Kualitatif. Bandung: Remaja Rosdakarya.

Neumann, W. L. (2006). Social Research Methods, Qualitative and Quantitative Approaches, 6th Edition. Boston: Pearson Education. Inc.

Sugiyono. (2009). Metode Penelitian Kuantitatif, Kualitatif, dan R\&D. Bandung: Alfabeta. 